\title{
The Impact of Entrepreneurial Marketing and Business Development on Business Sustainability: Small and Household Footwear Industries in Indonesia
}

\author{
Ma'mun Sarma ${ }^{1}$, Stevia Septiani ${ }^{1}$, Farida Ratna Dewi ${ }^{1}$ \& Edward H. Siregar ${ }^{1}$ \\ ${ }^{1}$ Faculty of Economics and Management, Bogor Agricultural University, Bogor, Indonesia \\ Correspondence: Ma'mun Sarma, Department of Management, Faculty of Economics and Management, Bogor \\ Agricultural University, Jalan Kamper, Kampus IPB Darmaga, Bogor 16680, Indonesia. Tel: 62-251-862-6435. \\ E-mail:mamun_sarma@yahoo.com
}

Received: April 25, 2013

Accepted: May 13, 2013 Online Published: May 28, 2013

doi:10.5539/ijms.v5n4p110

URL: http://dx.doi.org/10.5539/ijms.v5n4p110

\begin{abstract}
Entrepreneurial marketing is a marketing approach that is more appropriate in terms of resource constraints and problems that exist in small and medium enterprises (SMEs). Although the footwear industry is one of the government-supported SMEs sector in Indonesia, the development of the industry is still relatively slow. Various government policies have been implemented related to export and import settings, but it does not seem to provide significant benefits to the national development of the footwear industry. The main purpose of this study is to formulate a model of entrepreneurial marketing for business development and sustainability of small and household footwear industries based on the analysis of structural equation modeling (SEM) with partial least squares (PLS), entrepreneurial marketing shows positive influence on the development of the value of path coefficient of 0.511 (alpha $=5 \%$ ). In addition, the ability of entrepreneurial marketing also has a positive influence on the value of business sustainability path coefficient of 0.430 (alpha $=5 \%$ ). This positive influence means that businesses with a higher ability of entrepreneurial marketing will have higher levels of business development and sustainability. It can be concluded that entrepreneurial marketing plays an important role in shaping business development and sustainability of small and household footwear industries.
\end{abstract}

Keywords: entrepreneurial marketing, business development, business sustainability, footwear industry, household and small industries

\section{Introduction}

\subsection{Background}

The owners of SMEs implement marketing concepts in a different way than traditional marketing concept (Kraus et al., 2007). Although the marketing concept has been widely described in various textbooks, the marketing concept that was originally developed for large companies cannot be directly transferred to small businesses without adaptation. It illustrates that much of this marketing concept approach needs to be adjusted to be in line with the characteristics of SMEs that face special problems, as opposed to big companies.

Entrepreneurial marketing is a concept that is a more appropriate approach in terms of resource constraints and problems that exist in SMEs (Stokes, 2000). The concept of entrepreneurial marketing explores the values, skills, and behaviors of an entrepreneur in addressing their problems and finding business opportunities (Hadiyati, 2009). In practice, these concepts tend to be oriented to innovation and tailoring products to consumer demand. This is particularly relevant to the characteristics to the SMEs of the footwear industry, which are sensitive to changes in the model variant, thus requiring appropriate innovation strategy.

The footwear industry is a promising industry in the future for the growth of the Indonesian economy. Its existence as one of the government's non-oil backed small and medium industries (SMIs) in the National Medium Term Development Plan (Presidential Decree Number 7/2005) makes this industry especially important to develop. The development of the industry can be achieved through the implementation of an innovation strategy that is a form of creativity generated by the business manager (Rofiaty, 2010), which is also a reflection of the application of the concept of entrepreneurial marketing. 


\subsection{Urgency of the Research}

Although the presence of the footwear industry, especially small and household footwear industries, is very promising for the Indonesian economy, the industry is still experiencing development problems. Some government policies such as the imposition of the export tax of raw and semi-finished leather in order to secure the supply of raw materials (leather), as well as raising tariffs by Special Importer Identification Number in order to increase security and market development in the country, does not seem to provide significant benefits for national development of the footwear industry. Developing the industry should be integrated and balanced between each stakeholder. This is consistent with research by Utami (2007) whereas this research states that an effective empowerment model for craftsmen is to improve the quality of entrepreneurial behavior and independent efforts, supported by elements of the local government, non-government organizations and universities.

The development of entrepreneurial skills in marketing businesses is crucial for entrepreneurial efforts toward independence. This refers to the statement of Stokes (2000) that the concept of entrepreneurial marketing focused on elements of innovation and development of ideas in accordance with market development is the key to the survival, development and success of small businesses. On the basis of these conditions, a model of entrepreneurial marketing for the development and sustainability of small businesses in the footwear industry needs to be formulated.

\subsection{Objective of the Research}

The purpose of this study is to obtain the following information:

1) Understand the characteristics of small craftsmen, industry profiles and household footwear.

2) Create a model for the development of entrepreneurial marketing for business development and sustainability of small and household footwear industries.

3) Understand the extent of achievement of the capabilities of each of the key indicators of entrepreneurial marketing, business development and sustainability of small and household footwear industries.

\section{Theoretical Background and Conceptual Framework}

\subsection{Entrepreneurial Marketing}

Entrepreneurial marketing is a concept that originally appeared in small scale businesses or new start up business. This is consistent with the view of Kotler in Bjerke and Hultman (2002), which categorizes entrepreneurial marketing as marketing in the early development stages of a business. The concept of entrepreneurial marketing as a retailer marketing concept growing through entrepreneurship (Bjerke and Hultman, 2002) that is considered more appropriate to the problem and the limited resources available to the SMEs (Stokes, 2000). Through an entrepreneurial marketing approach, small businesses can create more focused business conditions related to the achievement of targeted objectives.

Based on general marketing perspectives, entrepreneurial marketing is positioned as a complement of the existing marketing theory (Bjerke and Hutlman, 2002). In addition, these two concepts are similar in terms of value creation for the sustainability of the business, but there are some differences in the characteristics of each concept. Stokes (2000) summarizes the differences between traditional marketing and entrepreneurial marketing in the following Table 1.

Table 1. Comparison of traditional marketing and entrepreneurial marketing

\begin{tabular}{lll}
\hline $\begin{array}{l}\text { Principles of } \\
\text { Marketing }\end{array}$ & Traditional Marketing & Entrepreneurial Marketing \\
\hline Concept & $\begin{array}{l}\text { Consumer-oriented (market forces), } \\
\text { product development through formal } \\
\text { assessment }\end{array}$ & $\begin{array}{l}\text { Oriented innovation (encouragement of ideas), } \\
\text { assessment of market needs intuitively }\end{array}$ \\
\hline Strategy & $\begin{array}{l}\text { Top-down approaches of segmentation, } \\
\text { targeting, and positioning }\end{array}$ & $\begin{array}{l}\text { Bottom-up approaches from consumer and } \\
\text { other influenced group }\end{array}$ \\
\hline Method & Marketing mix, 4Ps/7Ps & $\begin{array}{l}\text { Interactive marketing method, word-of-mouth } \\
\text { marketing, and direct selling }\end{array}$ \\
\hline $\begin{array}{l}\text { Market } \\
\text { Intelligence }\end{array}$ & $\begin{array}{l}\text { Formal research market and intelligence } \\
\text { system }\end{array}$ & Informal networks and information gathering \\
\hline
\end{tabular}

Source: Stokes (2000). 
In accordance with the four principles of marketing, which is used in the comparison of traditional marketing and entrepreneurial marketing, a more in-depth exposure is presented as follows (Stokes, 2000):

1) On the principle of "concept" that discussed the business orientation, note that unlike traditional marketing which is defined by the customer orientation, entrepreneurial marketing defined by entrepreneurship and innovation. Small business owners tend to be innovation-oriented, driven by new ideas and intuitive of the market, or driven by a rigorous assessment of the needs of the market.

2) At the strategic level, traditional marketing requires a top-down approach and a clear sequence of events such as segmentation, targeting and positioning to make the target market. On the other hand, a successful SME entrepreneur practices the opposite of traditional marketing, the bottom-up approach: (1) identifying market opportunities, and then testing them through trial and error, (2) thereafter, serving the needs of multiple clients, and then expanding by making direct contact with the clients, and knowing their preferences and needs, and (3) then, adding new customers with similar profiles to their old clients. This process often takes place accidentally, such as new customers that come as a result of early customer recommendation. Therefore, the target market is formed by the process of elimination and selection independently.

3) On the principle of "method" or the tactical level, the small businesses prefer interactive marketing methods rather than the model 4 Ps or 7 Ps. Through interactive marketing, they are trying to make direct and personal contact with customers. This interaction happens when employers do personal selling and relationship marketing activities. Furthermore, the results of the enhanced interaction improve word-of-mouth marketing.

4) In terms of "market intelligence" related to environmental monitoring marketing, small-scale entrepreneurs prefer to use informal methods such as observation or the collection of personal information through their network of contacts, rather than formal market research. Rejection of formal research methods is a logical consequence of the fact that the majority of them do not believe in the ability to predict the future.

\subsection{Business Development}

Based on her results, Utami (2007) recommends two methods in craftsmen business development strategies, namely: (1) improving the quality of business conduct and independence of business, and (2) the institutional effort with support from local governments, NGOs, and universities. The balance between institutional quality and business conduct of business creation is the key to good business development, including the small business footwear industry.

Parallel to the above statement, Hubeis (1997) states that several small industrial empowerment strategies are: (1) improved understanding (a way of thinking) about the decision-making process to formulate and find alternative solutions at hand, (2) an increase in the ability to recognize the environment to find and create comprehensive and integrated business opportunities through effective and prospective business planning, (3) creating a competitive advantage by reducing production cost, increasing product differentiation, finding market opportunities that are underutilized by the competitors, and mastery of market information (market intelligence), (4) selecting and implementing business cooperation through various channels, either temporary or permanent, in the form of backward (suppliers) or forward linkages (seller) simultaneously, and (5) improving the quality of human resources through professionalism empowerment (skills, knowledge and business ethics), learning organization, mutual communication and reactive-proactive thinking, and institutional development (training, internships, and business incubation).

\subsection{Business Sustainability}

The business entity that is engaged in agribusiness and industrial processing and serves as a driving force for agricultural development, requires systems and business competitiveness, and people oriented, sustainable, equitable and decentralized approaches (Slamet, 2003). Similarly, the domestic industries/small footwear increasingly faces stiff competition. Empowering businesses requires understanding how businesses can innovate, collaborate, integrate and excel in order to compete technically, economically, and socially, which in turn can maintain business continuity (Nurlina, 2009).

Business independence is reflected in the form of ability to do a job properly and correctly in accordance with the capacity that exists within him/her self. Entrepreneurial skills are intended acquisition capabilities including knowledge, skills, and attitudes reflected with an added value of the previous state. According to Jauch and Glueck (1992) a company or an industrial activity will continue to exist throughout the sustained operation of projects, agreements and ongoing activities. To maintain business continuity after the earthquake, Kuncoro (2001) suggested a strategy of Local Economic Development (LED) that focuses on endogenous development, the potential use of human resources, institutional, and physical/local consideration. 


\subsection{Structural Equation Modeling (SEM)}

Ghozali et al (2005) states that Structural Equation Modeling (SEM) is a multivariate statistical analysis technique, which can examine the complex relationship between recursive and non-recursive variables to obtain an overall picture of a model. SEM is technically divided into two groups, namely covariance-based SEM that is represented by LISREL and SEM software-based variance that is often called Component-Based SEM, which uses SmartPLS or PLS (Partial Least Squares) Graph software. Covariance-Based SEM aims at providing a statement about causality or a description of the mechanism of causality (cause and effect). While Component-Based SEM with PLS aims to find the predictive linear relationships between variables (Ghozali, 2008).

Covariance-Based SEM or SEM through an approach known as PLS analysis is a powerful method because it can be applied to any type of data scale (distribution free), which does not assume a particular distribution of data so that the data could be nominal, category, ordinal, interval and ratio. It can be used as a confirmation of the theory; SEM with PLS approach can also be used to build a relationship for testing theories or propositions (Ghozali, 2008).

\subsection{Transformation of Index}

Transformation of index is one quantitative technique that can identify the value of diversity that occurs in each of the study variables that are ordinal scale (Sumardjo, 1999). Measurement parameters or indicators of each variable are done to obtain information about the level of achievement in a continuum of the lowest total value (equal to the number of indicators) and the highest (equal to the maximum score), whereas each indicator scale is the ordinary scale score it. Achievement of each parameter through this analysis can be used as basis in the formulation of the next managerial decisions.

\subsection{Conceptual Framework}

Considering the importance of entrepreneurial marketing efforts on small scale enterprises, the study will establish a model of the development of entrepreneurial marketing for small and household footwear industries' business development and sustainability. The conceptual framework is presented in Figure 1.

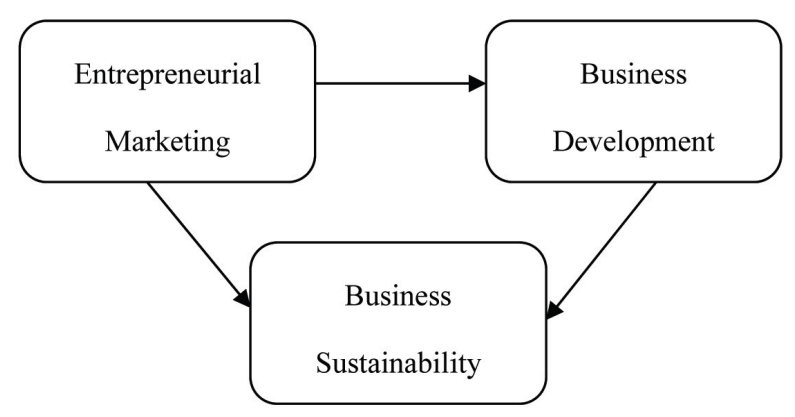

Figure 1. Conceptual framework

\subsection{Hypotheses}

Based on the conceptual framework and review of the literature prior to the research, the hypotheses for this study are formulated as follows:

H1: Entrepreneurial marketing positively influences the development of household and small footwear industries in Bogor region, Indonesia

H2: Business development positively influences the business sustainability of household and small footwear industries in Bogor region.

H3: Entrepreneurial marketing positively influences the business sustainability of household and small footwear industries in Bogor region. 


\section{Methodology}

\subsection{Time and Location}

This study is located in the Sub District of Ciomas to represent the District of Bogor and the Sub District of South Bogor to represent the city of Bogor. Bogor region in this study means Bogor District and Bogor city, in the Province of West Java. Bogor region is one of the central production areas of the footwear industry in Indonesia. The study was conducted over a period of three months (June to August 2012).

\subsection{Sample and Sample Procedure}

The sample was selected by non-probability sampling, using purposive cluster sampling. The ratio of footwear businesses in the district of Bogor and the city of Bogor is 1:3, so that sample used was 75 businesses from the district of Bogor and 25 businesses from the city of Bogor for a total sample of 100 entrepreneurs.

\subsection{Data Collection Method}

The data collection methods used was: questionnaires, field observations, interviews (including in-depth interviews), documentation study and assessment sheet. Primary data collection was generally obtained through the quantitative information provided by the respondents from household and small footwear industries. Then the data was classified based on the variables that were described with qualitative data, both derived from the respondents from household and small footwear industries as well as from agencies or related parties.

\subsection{Data Processing and Analyzing}

From the results of structured interviews using questionnaires, research data are then processed by multiple analysis techniques as follows: (1) descriptive statistical analysis is used to view the distribution or the distribution of categories of the variables, (2) the analysis of SEM by PLS approach to look at the direct and indirect effects between the variables as well as to formulate a model of the development of household and small footwear industries, and (3) transformation analysis of index (Sumardjo, 1999) for measuring the achievement of each of the key indicators of the outcome from SEM/PLS analysis.

\section{Results and Discussion}

\subsection{Characteristics of the Household and Small Footwear Industries}

The majority of footwear business owners ( $47 \%$ ) are elementary school graduates. Old craftsmen, 40 to 50 years old ( $43 \%$ of respondents) contributed largely to the low level of entrepreneurs' education, whose average is just graduated from elementary school. However, the percentage neither of entrepreneurs who are productive nor less magnitude (42\%) with age ranges between 30 years to 40 years. Age, education, socioeconomic status, relationship patterns, and attitudes affect one's innovation process (Slamet, 2003:16). Thus, with the mindset and life conditions like this make the most of them (76\%) were never out of the area to conduct business.

Most of the business owners in the footwear industry in Bogor region are male (92\%). This is because many men (48\%) worked in footwear workshops before setting up business independently. Seventy-three percent of the business owners pioneered their own way without any previous family experience in the industry. Even in running footwear business, the businesses often face difficulties; limited expertise in other fields make many of the business owners $(37 \%)$ rarely wish to relocate the business.

\subsection{Profile of the Household and Small Footwear Industries}

Most businesses in the footwear industry in the Bogor region are small industries (54\%). On average, worker-owned businesses have about 5 workers, with average turnover of 100-250 kodi ( 1 kodi=1.67 dozen pair of shoes) per month (53\%), the amount of turn over between 10 million to 30 million rupiah (equal to 1,000 to 3,000 USD) per month (39\%). The footwear industry in Bogor region is still relatively small, meaning that many of the footwear businesses in the region (64\%) face limitations in terms of resources. The majority of footwear enterprises in Bogor region are still inadequate in terms of the means of production (58\%), capital (51\%) and human resources (64\%). However, since most of them (87\%) do not have additional businesses, many of them (70\%) still make the footwear industry a priority.

\subsection{SEM PLS Analysis of Entrepreneurial Marketing and Business Development toward the Business Continuity of Household and Small Footwear Industries}

In this study, three latent variables were measured: entrepreneurial marketing (EM), business development (BD) and business sustainability (BS). Each latent variable has several manifest variables (indicators), which are reflective indicators obtained by conceptualization based on appropriate literature. Furthermore, SEM PLS 
analysis is performed including analysis of the outer model (measurement model) and the inner analysis model (structural model).

The outer model is a model that defines the relationship between the indicators and latent variables. The evaluation model can be determined by calculating the outer loading factor on the value of each indicator. Reflective indicators with latent variables are categorized to be high if they have a loading factor value of more than 0.7. However, to study the early stages of development, the value of a loading factor of 0.5 to 0.6 is considered sufficient (Chin, 1998 in Ghozali, 2008). Because this model is included in the model of the development phase, the indicators with loading factor values less than 0.6 will be deleted.

On the other hand, the inner model is a model that describes the significance of the relationship and the level of influence among latent variables. The significance of the relationship is obtained through bootstrapping techniques that ultimately results in the value of a T-statistic. In addition, the amount of influence between variables is indicated by the value of the coefficient on each path there.

\subsection{Analysis of Outer Model}

A reflective mode test was conducted according to five criteria: Loading factor, Composite Reliability, Average Variance Extracted (AVE), the square root of AVE, and Cross Loading (Ghozali, 2008). Based on Table 2, it is determined that this model meets the standard value on each outer criterion of existing models. Thus, it can be concluded that this model has good validity and reliability.

Table 2. Assessment criteria and the standards value of reflective mode

\begin{tabular}{|c|c|c|c|c|}
\hline No. & Criteria & Explanation & The Standard & Assessment Criteria \\
\hline 1. & Loading factor & $\begin{array}{lr}\text { The power } \\
\text { indicator in } \\
\text { reflecting } \\
\text { latent variable }\end{array}$ & $\geq 0.60$ & $\begin{array}{l}\text { All indicators show: loading } \\
\text { factor } \geq 0.60\end{array}$ \\
\hline 2. & $\begin{array}{l}\text { Composite } \\
\text { Reliability }\end{array}$ & $\begin{array}{l}\text { Internally } \\
\text { consistent }\end{array}$ & $>0.60$ & $\begin{array}{l}\mathrm{EM}=0.85 \\
\mathrm{BC}=0.80\end{array}$ \\
\hline 3. & $\begin{array}{l}\text { Average Variance } \\
\text { Extracted (AVE) }\end{array}$ & Construct Validity & $>0.50$ & $\begin{array}{l}\mathrm{EM}=0.53 ; \quad \mathrm{BD}=0.62 ; \\
\mathrm{BS}=0.67\end{array}$ \\
\hline 4. & $\begin{array}{l}\text { Root Square of } \\
\text { AVE }\end{array}$ & $\begin{array}{l}\text { Discriminant } \\
\text { Validity }\end{array}$ & $\begin{array}{l}\text { Greater than the value } \\
\text { of the correlation } \\
\text { between variables }\end{array}$ & $\begin{array}{l}\text { All values of the square root } \\
\text { from the AVE of latent } \\
\text { variables are greater than } \\
\text { correlation to the other latent } \\
\text { variables }\end{array}$ \\
\hline 5. & Cross Loading & $\begin{array}{l}\text { Discriminant } \\
\text { Validity }\end{array}$ & $\begin{array}{l}\text { Each indicator has a } \\
\text { higher loading for } \\
\text { each latent measured, } \\
\text { compared with other } \\
\text { indicators to the other } \\
\text { latent }\end{array}$ & $\begin{array}{l}\text { All indicators of EM, BD and } \\
\text { BS have a greater correlation } \\
\text { to the latent correlation itself } \\
\text { than other latent }\end{array}$ \\
\hline
\end{tabular}

Source: Primary data.

Figure 3 shows that EM (Entrepreneurial Marketing) is a latent variable that has the most major indicators compared with other latent variables. Each indicator has a loading factor value above 0.7 , meaning that the interrelation of each indicator in reflecting the latent is in the high category.

Latent variable EM is reflected by five key indicators: EM20 (frequency of product diversification), EM22 (level of product diversity), EM31 (ability to establish rapport with the medium), EM32 (ability to establish relationships with big business), and EM33 (level of activity searching for business information). Thus, referring to the perception of entrepreneurs, ability of entrepreneurial marketing is when at least five main reflective indicators can be implemented optimally. Business capability in terms of product diversification is crucial to answer the challenge of change model variance, which is so fast in this industry. To be able to survive and compete, the footwear that is produced must be in accordance with market demand and tailored to the product life cycle in the industry, which is relatively short. In addition, survival and competitiveness takes a good ability in terms of market intelligence, ranging from making good networking between medium or large scale 
enterprises to the involvement of businesses in finding information for business development. By implementing those steps, these businesses can monitor the market environment and discover a variety of potential opportunities for the development and sustainability of their businesses.

If explored further, the entrepreneurs' good ability of EM is reflected in indicators that make up the sub-variables of concept and market intelligence. The sub variable of concept means forming innovation and product diversification, whereas market intelligence is related to informal networks and collecting market information. In this industry, ability in product diversification and market intelligence is needed. The footwear industry, which is so sensitive to changes in model variant, can be developed through optimal achievement of each of the key indicators that reflect the ability of good EM.

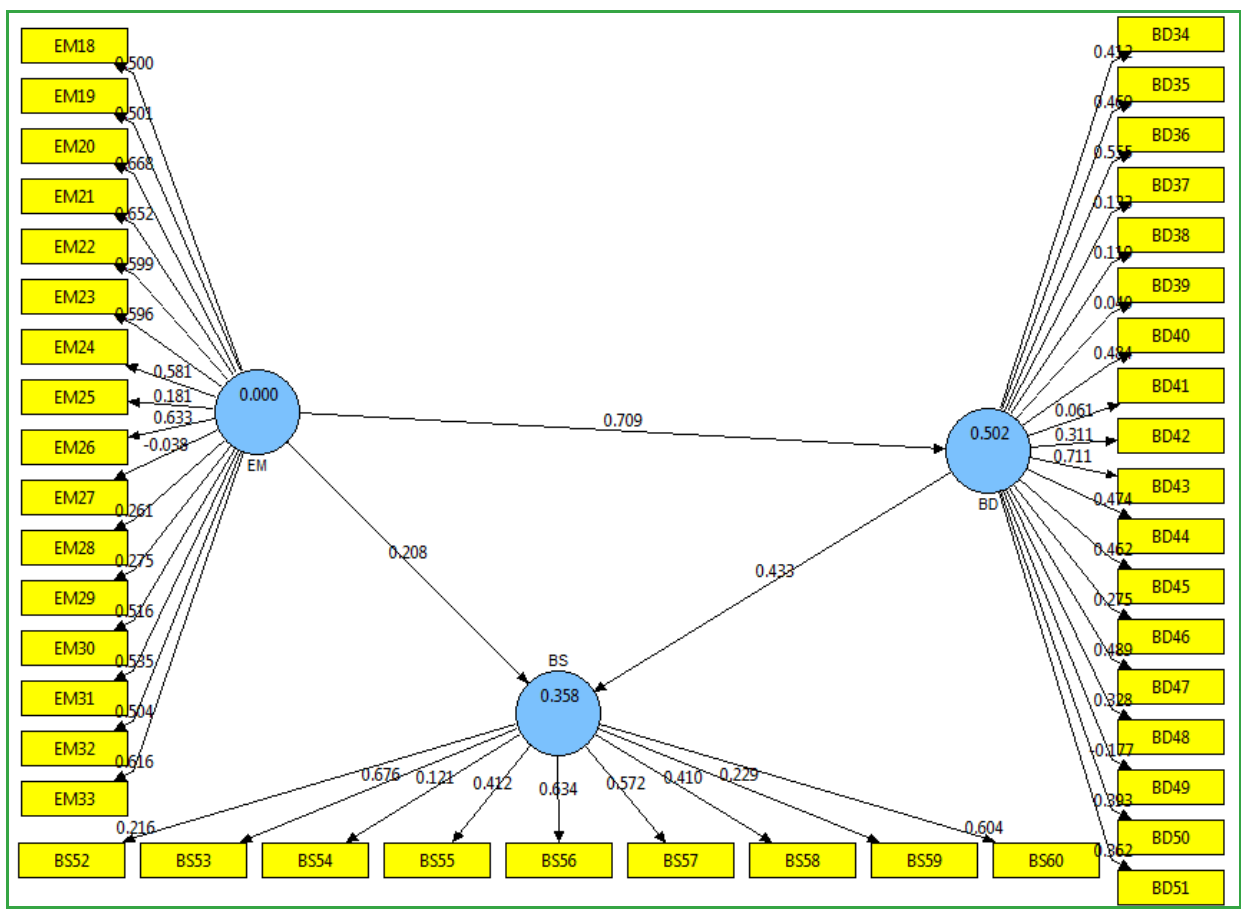

Figure 2. Early model

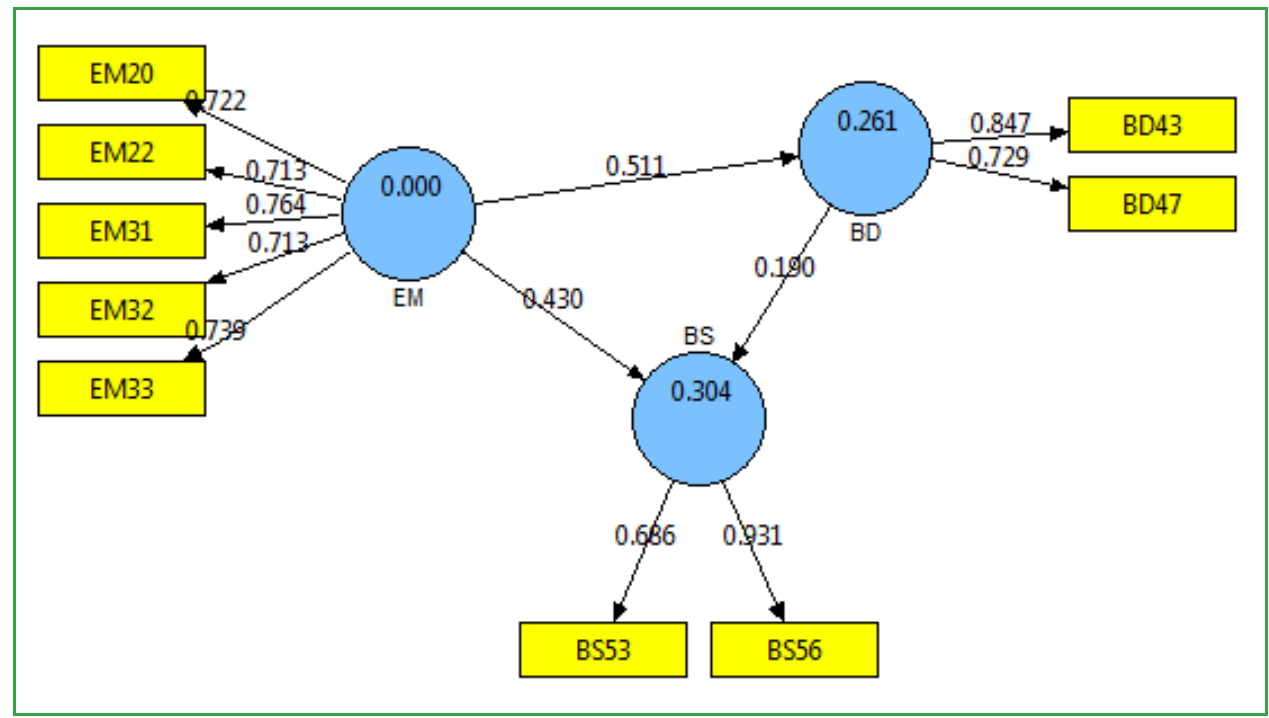

Figure 3. Final model 
Furthermore, BD (Business Development) latent variables are presented by two main indicators: BD43 (intensity develops potential) and BD47 (active entrepreneurs seeking capital opportunities from the government). By achieving optimal levels in both indicators, business development can be categorized as good.

The second loading factor of reflective indicators on BD latent variables is categorized as high (above 0.7). That is, both indicators contribute to representing good business development skills. Indicator BD43 (intensity develops potential) is the most important indicator in reflecting the development of the loading factor value of 0.847. This is understandable due to intensity developing the potential of human resources, equipment and capital, and it is a concrete step in the implementation of good business development in an industry. The presence of the BD47 indicator (active entrepreneurs seeking capital opportunities from the government) is also included in the main indicators of BD with loading factor values of 0.729 , indicating that active businesses in search of capital opportunities are supported by the existence of capital from the government as a major contributing factor to achieving good business development in this industry. Government intervention, especially in the case of capital, in reality is not fully implemented to the businesses as one of the important factors in developing businesses in household and small footwear industries.

On the other hand, there are two major indicators that reflect the BS (Business Sustainability) latent variable: BS53 (increasing the number of customers per year) and BS56 (success rate of new products sold to customers). Thus, the sustainability of the business can be good if at least two indicators have reached the optimum. Among the two main indicators of BS, the BS56 indicator (success rate of new products sold to customers) has the largest loading factor value of 0.931 . This illustrates that the success of the products sold to new customers is a key parameter in assessing the sustainability of the business in this industry. The success of new products sold to customers illustrates the degree of consumer acceptance of new footwear models offered by businesses, which in turn relates to potential sales and business sustainabality.

In general, these two indicators reflecting BS are included in the same scope of the discussion, i.e. the customers. The customers or the consumers are major contributors in representing business sustainability. This is consistent with the viewpoint of Crosier (1975), in which businesses are also classified as paying attention to the importance of organizational culture or the consumer market. Customer acceptance of new products is closely related to increases in the number of customers per year, so with the extent of impact of those two things can be seen on sustainability efforts for household and small footwear industries.

\subsection{Analysis of Inner Model}

In the inner model analysis, tests were carried out on two criteria: $\mathrm{R}^{2}$ of endogenous latent variables and the estimated path coefficients (Ghozali, 2008). The results of the data processing showed effects of the EM model on $\mathrm{BD}$ produced $\mathrm{R}^{2}$ of 0.261 , which means that $\mathrm{BD}$ latent variables can only be explained by the variability of EM latent by 26.1 percent. The influence of EM and BS models against BS has a $\mathrm{R}^{2}$ value of 0.304 , or latent $\mathrm{BS}$ variability can be explained by the variability of latent EM and BS by 30.4 percent. More analysis of the inner model can be seen in Table 3 below.

Table 3. Value analysis of the inner model versus the standard

\begin{tabular}{|c|c|c|c|c|}
\hline No. & Criteria & Explanation & The Standard & Assessment Criteria \\
\hline 1. & $\begin{array}{l}\mathrm{R}^{2} \text { of } \\
\text { endogenous } \\
\text { latent variables }\end{array}$ & $\begin{array}{l}\text { Endogenous variability } \\
\text { constructs which can be } \\
\text { explained by the } \\
\text { variability } \\
\text { exogenous constructs }\end{array}$ & $\begin{array}{l}\text { Chin (1998) classifies } \mathrm{R}^{2} \\
\text { value of } 0.67 ; 0.33 \text {, and } \\
0.19 \text { as "substantial", } \\
\text { "moderate" and "weak" }\end{array}$ & $\begin{array}{l}\mathrm{R}^{2} \text { for } \mathrm{BD}=0.261 \\
\mathrm{R}^{2} \text { for } \mathrm{BD}=0.304\end{array}$ \\
\hline 2. & $\begin{array}{l}\text { Estimated path } \\
\text { coefficients }\end{array}$ & $\begin{array}{l}\text { Evaluation of the value } \\
\text { of the coefficient, } \\
\text { covering real influence } \\
\text { through the bootstrap } \\
\text { method and the value of } \\
\text { the coefficient }\end{array}$ & $\begin{array}{l}\text { Significant effect, if } \\
\text { T-statistic > T-table. n } \\
\text { alpha } 5 \text { percent, the value } \\
\text { T-table is } 1.96\end{array}$ & $\begin{array}{l}\text { The value of T-statistic: } \\
\mathrm{EM}->\mathrm{BS}=8.525 \\
\mathrm{BD}->\mathrm{BS}=1.803 \\
\mathrm{EM}->\mathrm{BS}=5.108 \\
\text { The value of coefficient: } \\
\mathrm{EM}->\mathrm{BD}=0.511 \\
\mathrm{BD}->\mathrm{BS}=0.190 \\
\mathrm{EM}->\mathrm{BS}=0.430\end{array}$ \\
\hline
\end{tabular}

Source: Primary data. 
Through the bootstrapping method, the T-statistic values were obtained for determination of the statistical significance of the research model to test the hypothesis for each connection point. According to Figure 4, it is known that there are three paths, and only two paths that have a significant value (greater than the value of T-tables). BD and EM significantly influence the value of T-statistic of 8.525 (greater than T-tables). In addition, the latent EM also significantly influences BS with a value of T-statistic of 5.108 (greater than T-tables). On the other hand, BD latent variables do not show influence on the BS with a value of T-statistic of only 1.803 (smaller than T-tables), meaning that hypothesis 2 cannot be accepted.

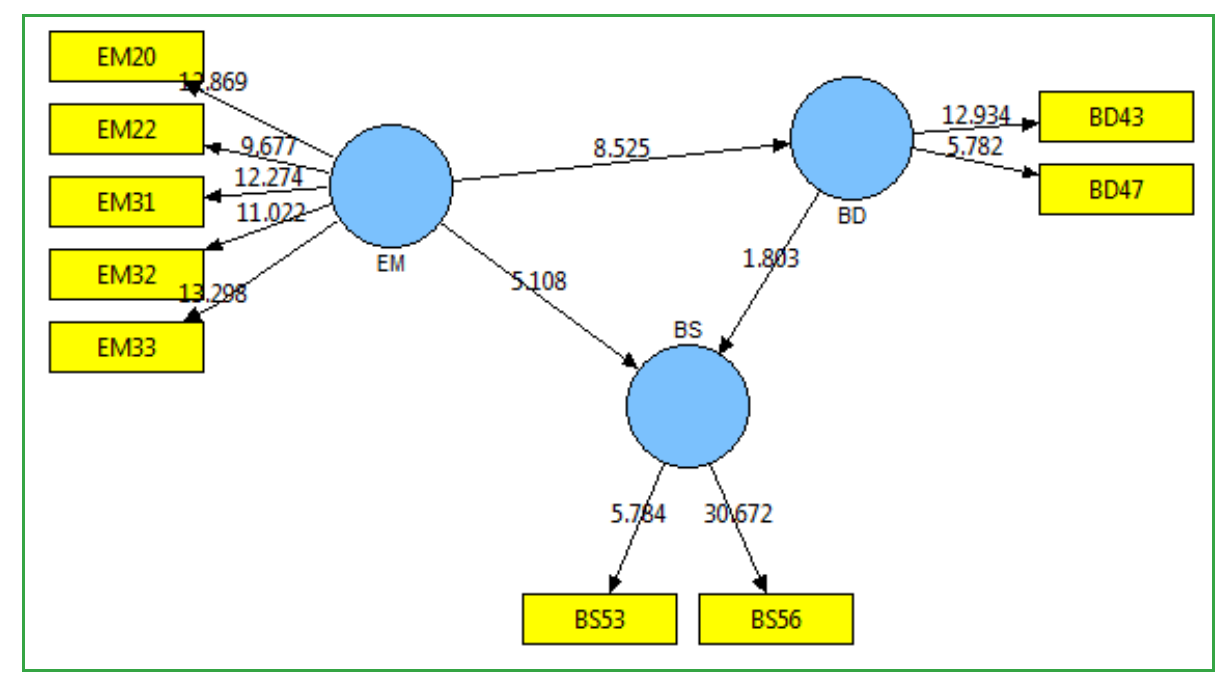

Figure 4. The Bootstrapping

Furthermore, the influence of the latent endogenous variable towards latent exogenous variable can be seen from the value of the coefficient on each path. It is known that the effect of EM on BD gave a positive coefficient equal to 0.511 , meaning that hypothesis 1 can be accepted. The effect of EM on BS has a positive coefficient that is smaller than the previous value, which reached 0.430 , which means that hypothesis 3 can also be accepted. The value path coefficients can be interpreted that when there is progress in the ability of entrepreneurial marketing, business development will increase by 51 percent. In addition, increasing the ability of entrepreneurial marketing can also improve the sustainability of the business by 43 percent. The results of this analysis indicate that the presence of entrepreneurial marketing is very important in determining the success of enterprise development and sustainability. This is in line with the opinion of Stokes (2000), who stated that entrepreneurial marketing is a key in determining the survival, development and success of small businesses.

\subsection{Analysis Capability of Entrepreneurial Marketing, Business Development and Business Sustainability} Indexes

Referring to the above SEM PLS analysis that produces a variety of key indicators that reflect each latent variable, the index was then analyzed to see how far each of these indicators have been implemented by the footwear businesses in Indonesia. The level of implementation of each of the key indicators will indicate the optimality and quality of achievement for latent variables of EM (Entrepreneurial Marketing), BD (Business Development) and BS (Business Sustainability).

In general, the indicators that reflect the latent entrepreneurial marketing, namely EM20 (frequency of product diversification), EM22 (level of product diversity), EM31 (ability to establish relationships with medium-sized businesses), EM32 (ability to establish relationships with large businesses), and EM33 (activity looking for business information), are still not optimal. The index score for each latent variable indicator of entrepreneurial marketing can be seen in Figure 5. The indicator EM32 (ability to establish relationships with large enterprises) is an indicator of the level of implementation and the index is the lowest (only 38 percent). Ability to establish informal networks and collecting market information is not yet completely formed, especially in the ability to establish relationships with large businesses. This is understandable given the lack of access to large enterprises, because of the rise of brokers. The brokers offer financial assistance the small and medium footwear industries, 
and then they have to sell the shoes to the brokers. In reality, through good networking with larger scale businesses, entrepreneurs can take advantage of potential opportunities for business advancement.

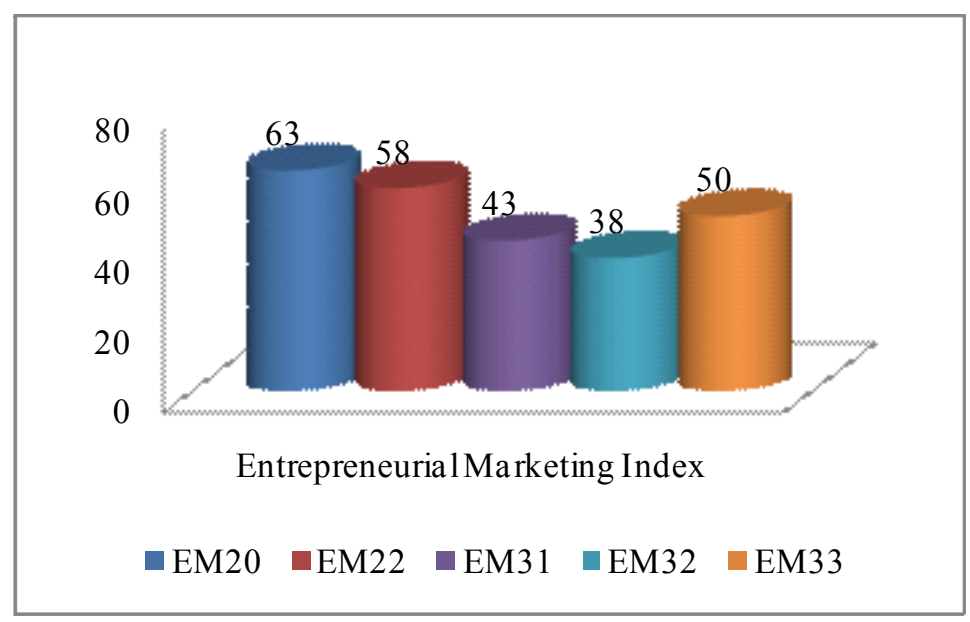

Figure 5. Entrepreneurial marketing index

Source: Primary data.

The same phenomenon is also found in the implementation of the key indicators that reflect BD (business development) variables. Based on Figure 6, note that the implementation of the two main indicators of business development, namely BD43 (intensity develops potential) and BD47 (active businessmen seeking opportunities the capital of the government), are still not optimal. So current development of household and small footwear industries is not so good. A low index score is found for indicator BD47 (active businesses seek opportunities from government capital), with a value of only 36 percent. These results illustrate that the majority of businesses are less active in seeking capital from the government. Based on the results of interviews, this happens because the majority of footwear businesses try to find financial assistance from the wholesale system called the "white bill". The "white bill" is cooperation between the footwear business with the wholesale system in terms of providing raw materials (capital) and product marketing. In this system, the wholesaler has a higher bargaining position than that of the footwear businesses. This is because the wholesalers are the owners of intact capital.

Capital is one of the key factors in the development of a business, including the household and small footwear industries. Although there are generally sources of funds available, the lack of common ground between the debtor and creditor banks leads to lack of financing (Widyastutik et al, 2010). According to the government, they have attempted to be as optimal as possible in facilitating the capital for the footwear small businesses. This is evidenced by the participation of several banks that have coordinated with the local government to help small businesses in the footwear industry. However, there is difficulty for businesses to meet all the requirements of the banks, and consistency has not yet been a focus of government support. This situation causes footwear businesses to prefer the "white bill", although they are more disadvantaged and unable to grow with this system. 


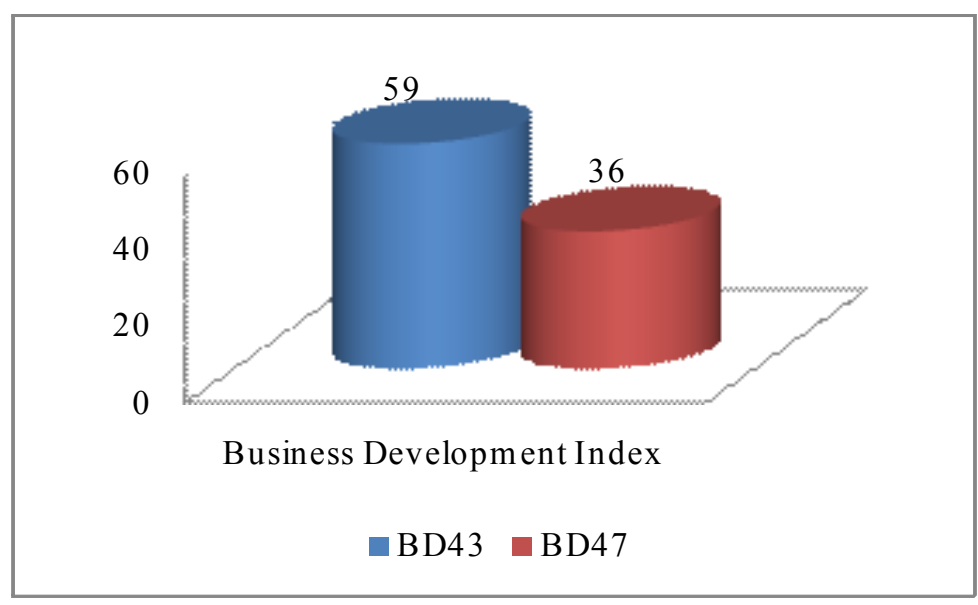

Figure 6. Business development index

Source: Primary data.

Furthermore, the index analyzes key indicators of business sustainability variables. There is not much difference from the previous discussion; it is known that the implementation of the two main indicators of business sustainability, namely BS53 (increase in the number of customers per year) and BS56 (success rate of new products sold to customers), are still not optimal yet. The index scores (in Figure 7) show the same achievement between the two indicators, which are both implemented at 60 percent. Although the value of this index is quite high compared to the index of $\mathrm{EM}$ and $\mathrm{BD}$, the value is not considered optimal because the index is still below the standard for high categories.

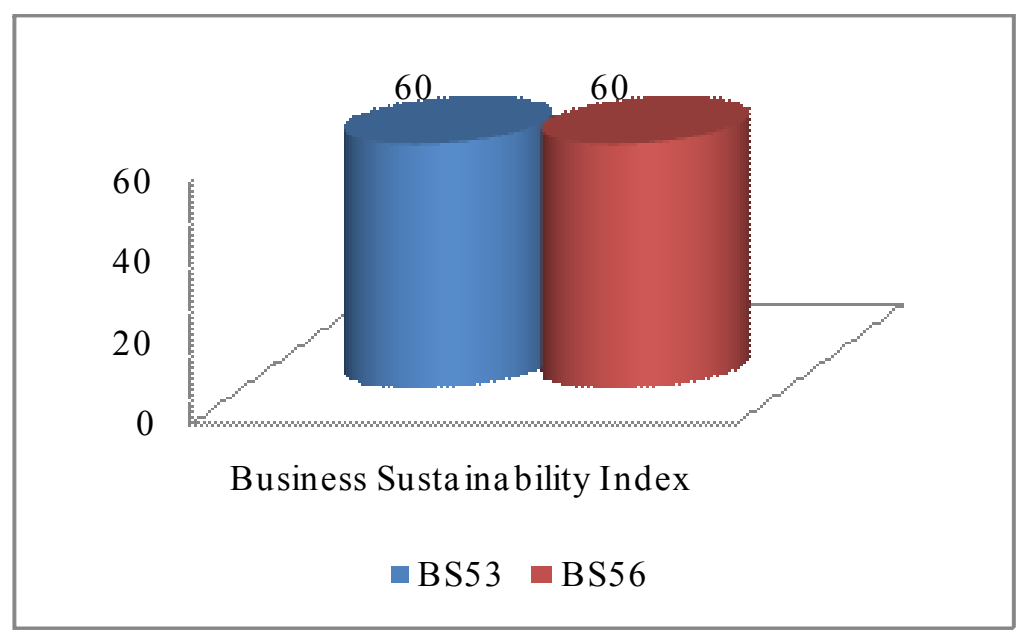

Figure 7. Business sustainability index

Source: Primary data.

\section{Conclusions and Recommendation}

Based on the analysis presented here, the following can be concluded:

1) Among entrepreneurs in household and small footwear industries in Bogor region, education levels are relatively low and business owners have a short-term mindset. However, they have excellent expertise in producing footwear. Furthermore, the characteristics of footwear enterprises in Bogor region including household and small industries are still limited in terms of the means of production, capital and human resources. However, the production of footwear is still used as the main source of business and income for these families.

2) Entrepreneurial marketing capabilities directly affect both business development and business sustainability. However, business development is not directly affected by business continuity. 
3) In general, based on the index analyses, the implementation of the key indicators that reflect each latent variable (entrepreneurial marketing, business development and business sustainability) is still not optimal.

Referring to the results of the analysis that has been described above, two main recommendations are proposed as follows:

1) There needs to be more optimal implementation of a range of key indicators that reflect each latent variable, in particular the ability to establish business relationships with large scale companies and active searching for capital from the government, where implementation is still very low.

2) There needs to be a compact collaboration of the businesses and the local governments in efforts toward sustainability in household and small footwear industries and handicraft footwear. There is an especially empowering role for local government to be a facilitator in terms of capital.

\section{Acknowledgments}

This research was funded by the national strategic competitive grant from the Directorate General of Higher Education, the Ministry of National Education and Culture, Republic of Indonesia under the contract number: 046/SP2H/PL/Dit.Litabmas/III/2012, March 7, 2012

\section{References}

Arikunto, S. (2002). Prosedur Penelitian Suatu Pendekatan Praktek (Research Procedure: A Practical Approach). Jakarta, Indonesia: Rineka Cipta.

Bjerke, B., \& Hutlman, C. M. (2002). Entreprenurial Marketing: The Growth of small firms in the new economic era. Gloucestershire: Edward Elgar.

Crosier, K. (1975). What exactly is Marketing? Quarterly Review of Marketing, 1(2), 21-50.

Ghozali, I. (2005). Structural Equation Modeling Teori, Konsep, dan Aplikasi dengan Program Lisrel 8.45 (Structural Equation Modeling: Theory, Concept and Application with Lisrel 8.45 Program). Semarang, Indonesia: Badan Penerbit Universitas Diponegoro.

Ghozali, I. (2008). Structural Equation Modeling Metode Alternatif dengan Partial Least Square Edisi 2. (Structural Equation Modeling: Alternative Method by Partial Least Square (2nd ed.)). Semarang, Indonesia: Badan Penerbit Universitas Diponegoro.

Hadiyati, E. (2009). Kajian Pendekatan Pemasaran Kewirausahaan dan Kinerja Penjualan Usaha Kecil. (A Study of Entrepreneurial Marketing Approach and Sales Performance of Small Enterprise). Jurnal Manajemen dan Kewirausahaa (Journal of Management and Entrepreneurship), 11(2), 183-192.

Hubeis, M. (1997). Menuju Industri Kecil Profesional di Era Globalisasi melalui Pemberdayaan Manajemen Industri. (Towards Small Industry Professionals in the Era of Globalization through Industrial Management Empowerment). Orasi Ilmiah Guru Besar Tetap Ilmu Manajemen Industri Fakultas Teknologi Pertanian IPB, Bogor.

Jauch, L. R., \& dan Glueck, W. F. (1992). Business Policy and Strategic Management. Singapore: McGraw-Hill Books Company.

Kraus, S., Fink, M., Rossl, D., \& Jensen, S. H. (2007). Marketing in Small and Medium Sized Enterprises. Review of Business Research, 7(3), 1-11.

Kuncoro, W. (2001). Analisis Profil dan Masalah Industri Kecil dan Rumah Tangga: Studi Kasus di Kabupaten Ngawi, Jawa Timur. (Profile Analysis and Problems of Small and Household Industries: A Case Study in Ngawi, East Java). Thesis. Yogyakarta, Indonesia: Magister Ekonomika Pembangunan UGM.

Nurlina, L. (2008). Hubungan Antara Tingkat Pelayanan Sarana Produksi dan Kegiatan Penyuluhan dengan Keberlanjutan Usaha Anggota Koperasi. (Relation between Input Service Level and Extension Activity With Cooperative's Member Sustainable Livelihood). Jurnal Ilmu Ternak. Fakultas Peternakan Universitas $\begin{array}{lllll}\text { Padjadjaran. } & \text { Retrieved } & \text { April } & \text { 2013, } & \text { from }\end{array}$ http://jurnal.unpad.ac.id/jurnalilmuternak/article/download/2215/2067

Nurlina, L. (2009). Hubungan Tingkat Partisipasi Peternak dengan Keberlanjutan Usaha Anggota Koperasi. (Relationships of Participation Rate between Breeders and Business Continuity of Cooperative Members). Jurnal Ekonomi Koperasi. Fakultas Peternakan Universitas Padjadjaran. Retrieved April 8, 2013, from http://pustaka.unpad.ac.id/wp-content/uploads/2009/12/hubungan_tingkat_partisipasi_peternak.pdf 
Rofiaty. (2010). Pengaru Turbulensi Lingkungan, Knowledge Sharing Behaviour, dan Strategi Inovasi terhadap Kinerja Usaha Kecil Menengah Kerajinan Sepatu Kulit di Mojokerto. (Effect of Environmental Turbulence, Knowledge Sharing Behavior, Innovation Performance Strategy for Small and Medium Craft Leather Shoes in Mojokerto, East Java, Indonesia). Jurnal Ekonomika-Bisnis (Journal of Economcs-Business), 2(2), 385-394. Retrieved July 31, 2012, from http://ejournal.umm.ac.id/index.php/jeb/article/viewFile/995/1062

Slamet, M. (2003). Pedoman Umum Penyelenggaraan Penyuluhan Pertanian dalam Pembangunan Sistem dan Usaha Agribisnis. (General Guidelines for the Implementation of Agricultural Extension in Development System and Agribusiness). Rahmat Prambudi dan Andriyono Kilat Adhi, Editor. Dalam Pemberdayaan Manusiaa Menuju Terwujudnya Masyarakat Madani. Bogor.

Stokes, D. (2000). Putting Entrepreneurship into Marketing. Journal of Research in Marketing \& Entrepreneurship, 2(1), 1-16. http://dx.doi.org/10.1108/14715200080001536

Sumardjo. (1999). Transformasi Model Penyuluhan Pertanian Menuju Pengembangan Kemandirian Petani. (Agricultural Extension Model Transformation Towards Independence Farmers Development). Dissertation. Bogor, Indonesia: Sekolah Pascasarjana IPB.

\section{Copyrights}

Copyright for this article is retained by the author(s), with first publication rights granted to the journal.

This is an open-access article distributed under the terms and conditions of the Creative Commons Attribution license (http://creativecommons.org/licenses/by/3.0/). 